\title{
Clavibacter: a New Genus Containing Some Phytopathogenic Coryneform Bacteria, Including Clavibacter xyli subsp. xyli sp. nov., subsp. nov. and Clavibacter xyli subsp. cynodontis subsp. nov., Pathogens That Cause Ratoon Stunting Disease of Sugarcane and Bermudagrass Stunting Disease $\dagger$
}

\author{
MICHAEL J. DAVIS, ${ }^{1 *}$ A. GRAVES GILLASPIE, JR., ${ }^{2}$ ANNE K. VIDAVER,${ }^{3}$ AND RUSSELL W. HARRIS ${ }^{2}$ \\ Agricultural Research and Education Center, Institute of Food and Agricultural Sciences, University of Florida, Ft. \\ Lauderdale, Florida 33314 ${ }^{1}$; Beltsville Agricultural Research Center, United States Department of Agriculture, Beltsville, \\ Maryland 20705 $;$ and Department of Plant Pathology, University of Nebraska, Lincoln, Nebraska $68583^{3}$
}

A total of 23 strains of coryneform bacteria that cause ratoon stunting disease of sugarcane and Bermudagrass stunting disease were examined. These included 17 sugarcane strains from Florida, Louisiana, South Africa, Brazil, and Japan and six Bermudagrass strains from Florida and Taiwan. The sugarcane and Bermudagrass strains contained 2,4-diaminobutyric acid, rhamnose, and fucose in their cell walls, suggesting a relationship to some other phytopathogenic coryneform bacteria and related organisms with similar cell wall compositions. The cellular protein patterns of the sugarcane and Bermudagrass strains after polyacrylamide gel electrophoresis resembled the patterns of Corynebacterium michiganense subspecies more than the patterns of some other diaminobutyric acid-containing taxa. The protein patterns of the sugarcane strains were distinct from the patterns of the Bermudagrass strains examined. The guanine-pluscytosine contents of the deoxyribonucleic acids of two sugarcane strains and one Bermudagrass strain were $66 \mathrm{~mol} \%$. The sugarcane and Bermudagrass strains formed a homogeneous group based on morphological characteristics and most biochemical characteristics. All of the sugarcane strains were nonpigmented (white) and grew more slowly in culture than the yellow-pigmented Bermudagrass strains. The Bermudagrass strains, unlike the sugarcane strains, hydrolyzed starch and utilized citrate and malate. Although the phytopathogenic coryneform bacteria with 2,4-diaminobutyric acid in the peptidoglycans of their cell walls are presently classified in the genus Corynebacterium, recent studies have indicated that these phytopathogens should be reclassified. These bacteria form a distinct group with characteristics different from those of all existing genera as presently circumscribed; therefore, we propose that a new genus, Clavibacter, be established for these and similar bacteria. We propose reclassification of Corynebacterium michiganense (including Corynebacterium michiganense subsp. michiganense, Corynebacterium michiganense subsp. insidiosum, Corynebacterium michiganense subsp. sepedonicum, Corynebacterium michiganense subsp. nebraskense, and Corynebacterium michiganense subsp. tessellarius), Corynebacterium iranicum, Corynebacterium tritici, and Corynebacterium rathayi in the new genus Clavibacter. We further propose that Clavibacter xyli be recognized as a new species with the following subspecies: Clavibacter xyli subsp. xyli sp. nov., subsp. nov., the species and subspecies type strain of which is sugarcane strain L1A (= ATCC $33974=$ NCPPB $3152=$ PDDC 7127), and Clavibacter xyli subsp. cynodontis subsp. nov., the subspecies type strain of which is Bermudagrass strain TB1A (= ATCC 33973).

The small, coryneform bacterium that causes ratoon stunting disease of sugarcane was recently isolated in axenic culture for the first time $(10,30)$. Ratoon stunting disease occurs in sugarcane throughout the world and is responsible for significant yield losses in many areas (44). This disease was originally thought to be caused by a virus until a bacterium was found by light and electron microscopy to inhabit the xylem vessels of sugarcane with ratoon stunting disease but not the xylem vessels of healthy sugarcane $(12$, $19,31,46,48)$. Strains of the bacterium were subsequently isolated from sugarcane from the United States, Brazil, Japan, and South Africa (10). All of the strains induced symptoms of ratoon stunting disease in inoculated sugarcane.

A bacterium resembling the ratoon stunting disease bacte-

\footnotetext{
* Corresponding author.

$\dagger$ Florida Agricultural Experiment Stations Journal Series no. 4803 .
}

rium also occurs in the xylem vessels of Bermudagrass in Taiwan (T. A. Chen, H. J. Su, B. C. Raju, and W. C. Huang, Abstr. Proc. Am. Phytopathol. Soc. 4:71, 1977). This bacterium was also isolated in axenic culture on the same complex media used to culture the ratoon stunting disease bacterium $(10,30)$. The Bermudagrass bacterium from Taiwan was experimentally shown to be pathogenic for Bermudagrass, causing a disease named Bermudagrass stunting disease (11); this disease is not known to occur in nature.

The Bermudagrass stunting disease and ratoon stunting disease bacteria are pathologically distinct, each inducing symptoms in its natural host but not in the natural host of the other bacterium (11). However, both bacteria are capable of multiplying in the xylem vessels of both hosts. Each pathogen has been found in nature only in the host in which it was first discovered. However, the ratoon stunting agent is experimentally transmissible to several graminaceous hosts, which, for the most part, remain symptomless (44). The host range of the Bermudagrass strains has not been determined. 
Strains of the ratoon stunting disease and Bermudagrass stunting disease bacteria have similar characteristics $(10,11$, 30 ). The strains are all gram positive, nonsporeforming, nonacid fast, oxidase negative, and catalase positive. They appear to divide by septate division, contain mesosomes, and are pleomorphic rods measuring 0.2 by 1 to $10 \mu \mathrm{m}$. Strains from sugarcane differ from strains from Bermudagrass in that the Bermudagrass strains grow faster in culture and produce a yellow, nondiffusible pigment. The two bacteria are serologically related, as determined by indirect fluorescent antibody staining and gel double-diffusion tests. In gel double-diffusion tests, the Bermudagrass strains have an additional antigenic determinant that is not present in sugarcane strains.

The amino acid and sugar compositions of the cell walls of the sugarcane and Bermudagrass strains are the same (11). The cell walls contain major amounts of 2,4-diaminobutyric acid, glycine, alanine, and glutamic acid. The major sugars are fucose and rhamnose. Peptidoglycan type $2 \mathrm{~B} \gamma$ of Schleifer and Kandler (40) is thought to occur. The cell wall compositions of the sugarcane and Bermudagrass strains provide evidence of a possible relationship to the plantpathogenic coryneform bacteria with similar cell wall compositions. However, a possible relationship between the ratoon stunting disease bacterium and the actinomycetes was suggested by Kao et al., based on morphological and chemotaxonomic analyses of cells extracted from diseased sugarcane (25; J. Kao, E. W. Blakeney, M. A. Gerencser, and K. E. Damann, Abstr. Phytopathol. 70:568, 1980). The extracted cells were sometimes filamentous, and ornithine or lysine or both ornithine and lysine, but not diaminobutyric acid, were identified in the cell wall preparations. Also, a deoxyribonucleic acid (DNA) guanine-plus-cytosine $(\mathrm{G}+\mathrm{C})$ content of $60 \mathrm{~mol} \%$ was reported for the bacteria in the extracts. Relationships with the actinomycetes or plantpathogenic corynebacteria have not been confirmed by serological methods. Strains in the genera Agromyces, Actinomyces, Arthrobacter, Corynebacterium, Myobacterium, and Nocardia have failed to react with antisera to the ratoon stunting disease bacterium in fluorescent antibody (11) and micro-agglutination tests (18).

We further examined the taxonomic relationships and characteristics of the sugarcane and Bermudagrass bacteria. The extremely fastidious nature of these two bacteria required modification of the media and conditions previously used for studies on coryneform bacteria. Therefore, insofar as possible, these bacteria and the type strains of phytopathogenic corynebacteria that appear on the Approved Lists of Bacterial Names (41) or have been validly published since 1 January 1980 were examined under identical conditions. Strains of Agromyces ramosus and Mycobacterium fortuitum were also included for comparison.

The phytopathogenic coryneform bacteria have been assigned in the past to the genus Corynebacterium (Lehmann and Neumann 1896) primarily on the basis of morphological and staining characteristics (27), but there is now general agreement $(7-9,15,23,50)$ that these bacteria do not belong to the genus Corynebacterium sensu stricto (22). Recent chemotaxonomic studies support transfer of Corynebacterium fascians to the genus Rhodococcus $(6,20)$, transfer of Corynebacterium ilicis to the genus Arthrobacter (9), and transfer of Corynebacterium flaccumfaciens (including Corynebacterium flaccumfaciens subsp. flaccumfaciens, Corynebacterium flaccumfaciens subsp. betae, Corynebacterium flaccumfaciens subsp. oortii, and Corynebacterium flaccumfaciens subsp. poinsettiae) to the genus Curtobacterium (8,
50). The remaining phytopathogenic coryneform bacteria are unusual in that they contain 2,4-diaminobutyric acid in their cell wall peptidoglycans $(4,7)$. Only a few saprophytic coryneform bacteria and the actinomycete Agromyces ramosus have similar cell wall compositions $(4,17)$. The taxonomic position of these 2,4-diaminobutyric acid-containing taxa remains unresolved $(1,7,47)$. Past and present data support our proposal that a new genus, Clavibacter, be created to accommodate the 2,4-diaminobutyric acid-containing phytopathogenic coryneform bacteria, including the ratoon stunting disease and Bermudagrass stunting disease bacteria. We propose that the ratoon stunting disease and Bermudagrass stunting disease bacteria be recognized as Clavibacter xyli sp. nov., with the sugarcane strains classified as Clavibacter xyli subsp. xyli and the Bermudagrass strains classified as Clavibacter xyli subsp. cynodontis. Other coryneform bacteria which contain 2,4-diaminobutyric acid in their peptidoglycans may belong in this new genus upon further comparison.

\section{MATERIALS AND METHODS}

Bacterial strains and media. The 17 sugarcane strains studied were from Brazil (strains B1A and B1B), Florida (strain F1), Japan (strains J1, J2, and J3), Louisiana (strains $\mathrm{L}_{1 A^{\mathrm{T}}}[\mathrm{T}=$ type strain], L2, L4, L5, L6, L7, L8, L9, and L10), and South Africa (strains S1A and S1B). The six Bermudagrass strains studied were from Florida (strains FB1 and FB2) and Taiwan (strains TB1A ${ }^{\mathrm{T}}$, TB1B, TB2A, and TB2B). The following four strains were deposited in the National Collection of Plant Pathogenic Bacteria (NCPPB), Harpenden, England, in the Plant Disease Division Culture Collection (PDDCC), Auckland, New Zealand, or in the American Type Culture Collection (ATCC), Rockville, Md.:

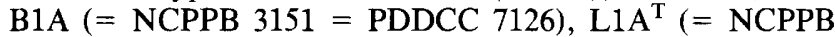
$3152^{\mathrm{T}}=\operatorname{PDDCC} 7127^{\mathrm{T}}=$ ATCC $\left.33864^{\mathrm{T}}\right), \mathrm{S} 1 \mathrm{~A}(=$ NCPPB $3150=\operatorname{PDDCC} 7215)$, and TB1A ${ }^{\mathrm{T}}\left(=\mathrm{ATCC} 33973^{\mathrm{T}}\right)$. The reference strains of Corynebacterium, Agromyces ramosus, and Mycobacterium fortuitum used and their sources are listed in Table 1.

All strains were stored in the freeze-dried condition. All biochemical tests were repeated at least once with fresh cultures from freeze-dried stocks. Cultures of the sugarcane and Bermudagrass strains were maintained on SC medium (10) at $28^{\circ} \mathrm{C}$. Stock cultures of all other strains were maintained on yeast extract-sucrose-chalk agar (16), yeast extract-salts agar (16), and 523 agar $(24)$ at $4^{\circ} \mathrm{C}$ and were transferred to $\mathrm{SC}$ medium at $28^{\circ} \mathrm{C}$ for working cultures. The RSD broth used as the basal medium for some biochemical tests contained $1,000 \mathrm{ml}$ of deionized water, $1 \mathrm{~g}$ of yeast extract, $1 \mathrm{~g}$ of $\left(\mathrm{NH}_{4}\right)_{2} \mathrm{HPO}_{4}, 0.2 \mathrm{~g}$ of $\mathrm{MgSO}_{4} \cdot 7 \mathrm{H}_{2} \mathrm{O}, 15 \mathrm{ml}$ of $0.1 \%(\mathrm{wt} / \mathrm{vol}$ ) hemin chloride stock (bovine; Sigma Chemical Co., St. Louis, Mo.) in $0.05 \mathrm{~N} \mathrm{NaOH}, 1 \mathrm{~g}$ of cysteine (free base), $0.2 \mathrm{~g}$ of $\mathrm{KCl}, 10 \mathrm{ml}$ of filter-sterilized $(0.2-\mu \mathrm{m}$ membrane filter) $20 \%$ (wt/vol) bovine serum albumin fraction 5 (Sigma), and $10 \mathrm{ml}$ of filter-sterilized $50 \%$ (wt/vol) glucose stock. This medium without the filter-sterilized ingredients was adjusted to $\mathrm{pH} 7.2$ with $0.1 \mathrm{~N} \mathrm{HCl}$ and autoclaved. The filter-sterilized ingredients were then added to the autoclaved ingredients. The final $\mathrm{pH}$ was 6.7 to 6.8 .

General methods. Gram staining (Hucker method) and acid-fast staining (Ziehl-Neelsen method) were performed as previously described (14). Morphology was examined by using negatively stained (1\% [wt/vol] phosphotungstic acid or $2 \%$ [wt/vol] ammonium molybdate, $\mathrm{pH} 7.0$ ) preparations and transmission electron microscopy. Oxygen require- 
TABLE 1. Reference strains ${ }^{a}$

\begin{tabular}{|c|c|}
\hline Species or subspecies & Strain \\
\hline Agromyces ramosus & ATCC 25173 \\
\hline Corynebacterium fascians & ATCC 12974 \\
\hline Corynebacterium fascians. & . ICPB CF19 \\
\hline $\begin{array}{l}\text { Corynebacterium flaccumfaciens subsp. } \\
\text { flaccumfaciens }{ }^{b} \ldots \ldots \ldots \ldots \ldots \ldots\end{array}$ & NCPPB 1446 \\
\hline Corynebacterium flaccumfaciens subsp. betae $b$ & NCPPB 374 \\
\hline Corynebacterium flaccumfaciens subsp. oortii & ATCC 25283 \\
\hline $\begin{array}{l}\text { Corynebacterium flaccumfaciens subsp. } \\
\text { poinsettiae }{ }^{b} \ldots \ldots \ldots \ldots \ldots \ldots \ldots \ldots \ldots\end{array}$ & \\
\hline Corynebacterium ilicis & ATCC 14264 \\
\hline Corynebacterium iranicum $\ldots \ldots \ldots \ldots$ & . NCPPB 2253 \\
\hline $\begin{array}{l}\text { Corynebacterium michiganense subsp. } \\
\text { michiganense }^{b} \ldots \ldots \ldots \ldots \ldots \ldots \ldots\end{array}$ & NCPPB 2979 \\
\hline $\begin{array}{l}\text { Corynebacterium michiganense subsp. } \\
\text { insidiosum }^{b} \ldots \ldots \ldots \ldots \ldots \ldots \ldots\end{array}$ & NCPPB 1109 \\
\hline $\begin{array}{c}\text { Corynebacterium michiganense subsp. } \\
\text { nebraskense }{ }^{b} \ldots \ldots \ldots \ldots \ldots \ldots\end{array}$ & NCPPB 2579 \\
\hline $\begin{array}{l}\text { Corynebacterium michiganense subsp. } \\
\text { sepedonicum }{ }^{b} \ldots \ldots \ldots \ldots \ldots \ldots \ldots\end{array}$ & ATCC 33113 \\
\hline $\begin{array}{l}\text { Corynebacterium michiganense subsp. } \\
\text { tessellarius }{ }^{c} \ldots \ldots \ldots \ldots \ldots \ldots \ldots\end{array}$ & Vidaver $7711 \mathrm{C}$ \\
\hline Corynebacterium rathayi $\ldots \ldots \ldots \ldots$ & NCPPB 2980 \\
\hline Corynebacterium tritici ....... & ATCC 11403 \\
\hline Mycobacterium fortuitum .. & ATCC 14467 \\
\hline
\end{tabular}

${ }^{a}$ ATCC, American Type Culture Collection, Rockville, Md.; NCPPB, National Collection of Plant Pathogenic Bacteria, Plant Pathology Laboratory, Harpenden, England; ICPB, International Collection of Phytopathogenic Bacteria, University of California, Davis.

${ }^{b}$ These names are on the Approved Lists of Bacterial Names (41) as separate species, but have been proposed as new combinations (1).

${ }^{c}$ Corynebacterium michiganense subsp. tessellarius is a new $\operatorname{tax}$ on (1).

ments were determined by streaking cultures on SC medium and incubating them for 21 days in a GasPak system (BBL Microbiology Systems, Cockeysville, Md.) with the following atmospheres: $5 \% \mathrm{CO}_{2}$ with $\mathrm{O}_{2}$ replaced with $\mathrm{H}_{2}, 5 \% \mathrm{CO}_{2}$ in air, and without a modified atmosphere. Oxygen requirements were also examined in duplicate tubes containing fresh soft SC medium $(0.6 \%$ [wt/vol] corn meal agar and $0.1 \%$ [wt/vol] glucose). Deep stab inoculations $(5 \mathrm{ml}$ in tubes [12 by $100 \mathrm{~mm}]$ ) were made, and one tube of each pair was covered with $1 \mathrm{~cm}$ of a sterile mixture of paraffin oil and petroleum jelly (1:1); growth was recorded visually after 7 , 14 , and 21 days.

The production of acid from carbohydrates and related carbon sources was tested by using modified RSD broth supplemented with $0.01 \%$ (wt/vol) yeast extract, $0.008 \%$ (wt/vol) bromthymol blue, and glucose or another test compound at a concentration of $0.5 \%(\mathrm{wt} / \mathrm{vol})$. Most of the test compounds were added to the autoclaved basal medium as $10 \%$ filter-sterilized stock solutions; exceptions were starch, inulin, and esculin, which were added to the basal medium before autoclaving. This same modified RSD broth without glucose was used to test for the utilization of organic acids. The organic acids were tested at concentrations of $0.1 \%$ (wt/vol) after being added to the basal medium as their sodium salts in $10 \%$ filter-sterilized stock solutions. Each test was performed in $2 \mathrm{ml}$ of medium in tubes ( 12 by 100 $\mathrm{mm})$. The medium was inoculated with $0.1 \mathrm{ml}$ of a turbid bacterial suspension in $0.01 \mathrm{M}$ phosphate buffer $(\mathrm{pH} 7.0$ ), and the culture was incubated at $28^{\circ} \mathrm{C}$ without agitation. Non-inoculated medium and inoculated medium without any test compound were maintained as controls. Results were recorded visually after 7,14 , and 21 days. Acid production and gas production were tested in stationary RSD broth cultures containing Durham tubes. The methyl red test was performed by adding 3 or 4 drops of a methyl red solution $(0.1 \mathrm{~g}$ of methyl red, $300 \mathrm{ml}$ of $95 \%$ ethanol, $200 \mathrm{ml}$ of distilled water) to a shaker-incubated RSD broth culture after 7 days; a strong red color was considered a positive reaction. Levan production was determined by using SC medium supplemented with $4 \%$ (wt/vol) sucrose; the development of domed, mucoid colonies within 7 to 14 days on streaked plates was considered positive.

The maximum temperature for growth was determined by incubating RSD broth cultures in temperature-controlled metal heat blocks at $1^{\circ} \mathrm{C}$ increments from 30 to $37^{\circ} \mathrm{C}$ and recording growth after 7,14 , and 21 days. $\mathrm{NaCl}$ tolerance was tested in stationary RSD broth cultures containing 1 to $10 \%$ (wt/vol) $\mathrm{NaCl}$; the tubes were examined for turbidity over a period of 21 days. KCN tolerance was determined by the ability of cultures to grow for 14 days in RSD broth supplemented with $0.0075 \%$ (wt/vol) $\mathrm{KCN}$ added as a $0.5 \%$ filter-sterilized stock solution. Catalase production was determined by removing a portion of a fresh colony on SC medium with a sterile toothpick and mixing the bacteria with a drop of $3 \%$ hydrogen peroxide; the production of bubbles was considered positive. Oxidase production was tested by the method of Kovacs (28). Lipase production was determined by using SC medium supplemented with $0.01 \%$ (wt/vol) $\mathrm{CaCl} \cdot \mathrm{H}_{2} \mathrm{O}$ and separately autoclaved Tween 20 , Tween 80 , or corn oil at a concentration of $1 \%(\mathrm{vol} / \mathrm{vol})$; the development of a cloudy precipitate in the medium around areas of growth was considered positive. Tyrosinase activity was determined by using RSD broth supplemented with $0.5 \%$ (wt/vol) tyrosine; the production of a reddish brown pigment in agitated broth within 14 days was considered positive. Urease activity was determined by using RSD broth supplemented with $0.0016 \%$ (wt/vol) cresol red and $1 \%$ (wt/vol) urea (filter-sterilized; $20 \%$ stock solution); the production of a magenta color within 14 days was considered positive. The vanillin method (39) was used to determine indole production; RSD broth cultures supplemented with $0.2 \%$ (wt/vol) glucose and $0.1 \%(\mathrm{wt} / \mathrm{vol})$ tryptophan were tested after 3, 5, 7, and 14 days of incubation. Acetoin production was determined by using $1-\mathrm{ml}$ portions of RSD broth cultures after $3,5,7$, and 14 days of incubation and the modified O'Meara creatine test (16). Nitrate (or nitrite) reduction was determined by using RSD broth supplemented with $0.3 \%$ (wt/vol) glucose and $0.1 \%$ (wt/vol) $\mathrm{KNO}_{3}$ (or $0.1 \%$ $\mathrm{NaNO}_{2}$ ); after 3, 5, 7, and 14 days of incubation, the production (or the persistence) of nitrite was tested with sulfanilic acid and dimethyl- $\alpha$-napthylamine (42). RSD broth cultures were tested for ammonia production by the method of Dye and Kemp (16) after 3, 5, and 7 days of incubation. Hydrogen sulfide production was tested with lead acetatecontaining strips suspended over RSD broth cultures; darkening of the strips indicated a positive reaction. Hydrolysis of starch was tested by using SC medium supplemented with $1 \%(\mathrm{wt} / \mathrm{vol})$ soluble potato starch. Heavy growth was removed from the agar, and clearing of the medium was tested with an iodine solution (42). Esculin hydrolysis was tested by using SC medium supplemented with $0.1 \%$ (wt/vol) esculin; development of a dark brown color in the medium indicated esculin hydrolysis.

Cell walls. Cell walls of strains $\mathrm{L}^{\mathrm{A}} \mathrm{A}^{\mathrm{T}}, \mathrm{S} 1 \mathrm{~A}$, and $\mathrm{B} 1 \mathrm{~A}$ from sugarcane, strain $\mathrm{TB}^{\mathrm{T}} \mathrm{A}^{\mathrm{T}}$ from Bermudagrass, and all reference strains were prepared and analyzed for amino acid 
composition and sugar composition by the methods of Lechevalier and Lechevalier (29), using thin-layer and descending paper chromatography. All strains were grown in S8 broth (10). The cells were harvested in the late log phase of growth, autoclaved, and stored frozen until 3 to $6 \mathrm{~g}$ of cells was collected for analysis. The amino acid compositions of strains $\mathrm{L}_{1 A^{\mathrm{T}}}, \mathrm{B} 1 \mathrm{~A}$, and $\mathrm{TB} 1 \mathrm{~A}^{\mathrm{T}}$ were also analyzed by gas chromatography. Approximately $1 \mathrm{~g}$ of cells was harvested from plates of SC medium, washed twice by centrifugation at $2,000 \times g$ for $15 \mathrm{~min}$, and suspended in distilled water at a concentration of $0.2 \mathrm{~g} / \mathrm{ml}$. The cell suspensions were disrupted by three passages through a French press. The cell wall fraction was purified by the method of Lechevalier and Lechevalier (29). $N$-Heptafluorobutyryl isobutyl esters of the cell wall preparations and amino acid standards were prepared by the direct esterification method of Rhodes et al. (38). Analyses were performed with a Perkin-Elmer model 115 gas chromatograph equipped with dual flame ionization detectors. The column packing used was 3\% SE-30 on 100/120 Gas-Chrom Q (prepacked 6-foot [1.83-m] Pyrex columns; Supelco Inc., Bellefonte, Pa.). The chromatography program was set up as follows: column temperature, 90 to $240^{\circ} \mathrm{C}$ at $4^{\circ} \mathrm{C} / \mathrm{min}$; injector temperature, $250^{\circ} \mathrm{C}$; detector temperature, $280^{\circ} \mathrm{C}$; hydrogen flow rate, $20 \mathrm{ml} / \mathrm{min}$; helium carrier flow rate, $20 \mathrm{ml} / \mathrm{min}$.

G+C content of DNA. Bacteria were grown in S8 broth as static suspension cultures containing $20 \mathrm{mM}$ L-threonine (2). Cells $(0.5$ to $1 \mathrm{~g})$ were washed twice by centrifugation at $2,000 \times g$ for $15 \mathrm{~min}$ and then suspended in $10 \mathrm{ml}$ of TAE buffer [ $40 \mathrm{mM}$ tris(hydroxymethyl)aminomethane, $20 \mathrm{mM}$ sodium acetate, $1 \mathrm{mM}$ ethylenediaminetetraacetic acid, $\mathrm{pH}$ 7.8]. About $500 \mu \mathrm{g}$ of lysozyme (Sigma) was added to the cell suspension, and the suspension was incubated at $37^{\circ} \mathrm{C}$ for 2 h. Sodium dodecyl sulfate was then added to a final concentration of $1 \%(\mathrm{wt} / \mathrm{vol})$, and incubation at $37^{\circ} \mathrm{C}$ was continued for $1 \mathrm{~h}$. The viscous lysate was then extracted with 0.5 volume of $8 \mathrm{M}$ lithium chloride (13) and TAE buffersaturated phenol (1:1). The mixture was kept on ice for $1 \mathrm{~h}$ with occasional agitation. The phases were then separated by centrifugation at $2,500 \times g$ for $10 \mathrm{~min}, 2$ volumes of cold $95 \%$ ethanol was added to the aqueous phase, and the preparation was incubated at $-20^{\circ} \mathrm{C}$ for $1 \mathrm{~h}$. The precipitate was collected by centrifugation at $5,000 \times g$ for $10 \mathrm{~min}$. The resulting pellet was dissolved in TAE buffer and dialyzed overnight against TAE buffer at $4^{\circ} \mathrm{C}$. Ribonuclease A (type I; Sigma) was added to a final concentration of $50 \mu \mathrm{g} / \mathrm{ml}$, and the mixture was incubated at $37^{\circ} \mathrm{C}$ for $30 \mathrm{~min}$. After ribonucleic acid digestion, the mixture was extracted with TAE buffer-saturated phenol to denature the enzyme and any remaining protein. The emulsion was then centrifuged at $2,500 \times g$ for $10 \mathrm{~min}$, and the aqueous phase was removed. The DNA was precipitated with $95 \%$ ethanol, centrifuged, dissolved in PE buffer $\left(10 \mathrm{mM} \mathrm{NaH} \mathrm{PO}_{4} / \mathrm{Na}_{2} \mathrm{HPO}_{4}, 1 \mathrm{mM}\right.$ ethylenediaminetetraacetic acid, $\mathrm{pH}$ 7.0), dialyzed overnight against $\mathrm{PE}$ buffer, and stored at $-20^{\circ} \mathrm{C}$. The DNA base composition was determined from the thermal denaturation temperature in PE buffer, as measured with a Gilford model 2400 spectrophotometer and a temperature programmer which was set for a $0.25^{\circ} \mathrm{C}$ increase per min. The $\mathrm{G}+\mathrm{C}$ content was calculated by the method of Marmur and Doty (32). DNA purified from whole-cell samples of Xanthomonas campestris pv. phaseoli NCPPB 1811 by the method described above was used as the standard $(63 \mathrm{~mol} \% \mathrm{G}+\mathrm{C})$ in one set of experiments (21). DNA from Micrococcus lysodeikticus D-5015 (Sigma) (72 mol\% $\mathrm{G}+\mathrm{C}$ ) was used as the standard in another set of experiments (21).

Polyacrylamide gel electrophoresis. Gradient slab gels were used as previously described (1), except that the cells were grown in RSD broth for standardization under the same conditions.

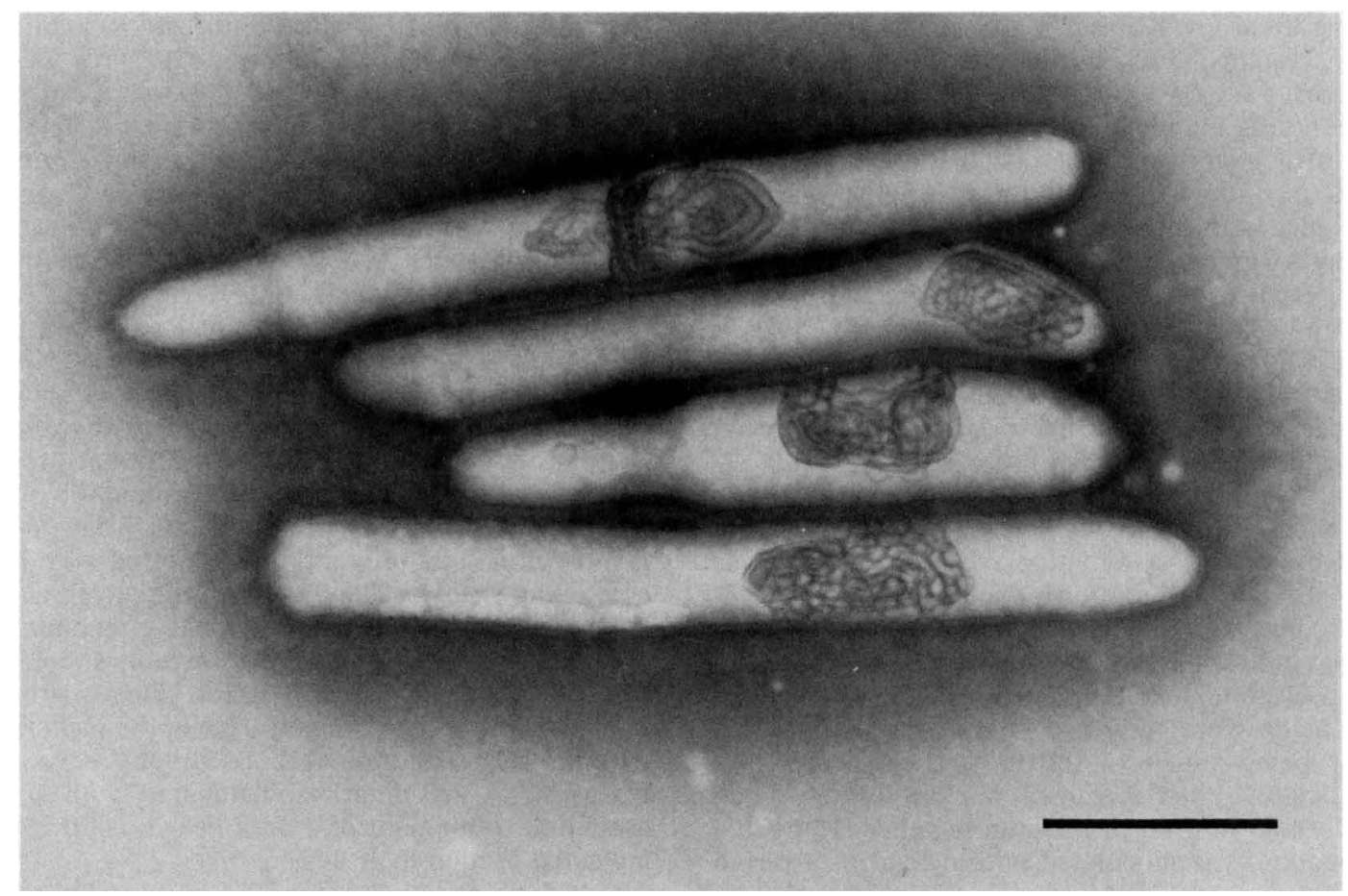

FIG. 1. Negatively stained preparation ( $2 \%$ ammonium molybdate) of sugarcane strain L1A ${ }^{\mathrm{T}}$, showing pleomorphic, rod-shaped cells with mesosomes. Bar $=0.5 \mu \mathrm{m}$. 


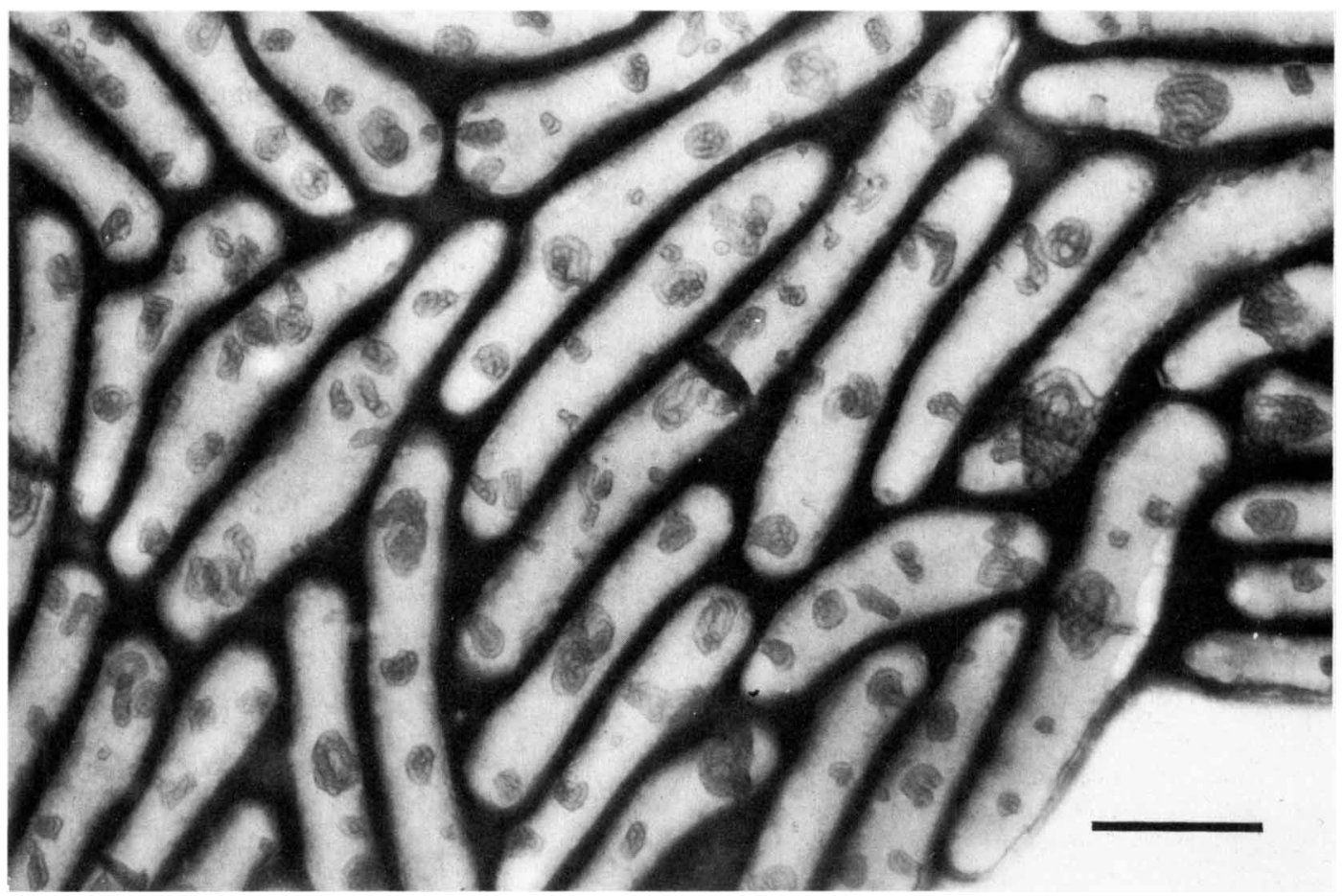

FIG. 2. Negatively stained preparation (1\% phosphotungstic acid) of Bermudagrass strain $\mathrm{TB}_{\mathrm{A}} \mathrm{A}^{\mathrm{T}}$, showing pleomorphic, rod-shaped cells with septa and mesosomes. Bar $=0.5 \mu \mathrm{m}$.

\section{RESULTS}

Morphology and cultural characteristics. Figures 1 and 2 are electron micrographs of strain $\mathrm{LlA}^{\mathrm{T}}$ from sugarcane and strain $\mathrm{TB} 1 \mathrm{~A}^{\mathrm{T}}$ from Bermudagrass, respectively. The cells of both strains were rod shaped with a pleomorphism characteristic of coryneform bacteria and measured 0.2 to 0.3 by 4.0 to $6.0 \mu \mathrm{m}$. The cells of both strains had septa and contained mesosomes. Neither strain had flagellated cells, nor was motility observed in agar or broth cultures. Endospores were not formed. The cells of both strains usually occurred singly or in pairs. All strains exhibited $\mathrm{V}$ forms in wet mounts of cells that were taken from both agar and broth media and observed by phase-contrast microscopy. Mycelial growth was not observed in colonies on SC agar or in suspensions from stationary broth cultures, although primary branching was occasionally observed.

The growth of all 17 strains from sugarcane on SC agar medium at $28^{\circ} \mathrm{C}$ was slow, with colonies becoming visible in 7 to 10 days; full colony development required 2 to 3 weeks. In contrast, the growth of all six strains from Bermudagrass was more rapid, with colonies becoming visible in 5 to 7 days and full colony development requiring 1 to 2 weeks. None of the strains grew on yeast extract-sucrose-chalk agar, yeast extract-salts agar, 523 agar, or nutrient agar. The colonies of all strains on SC medium were circular, convex, glistening, and butyrous and had entire margins. The colonies of the strains from sugarcane reached diameters of 0.1 to $0.3 \mathrm{~mm}$ and developed a white color. The colonies of the strains from Bermudagrass reached larger diameters $(0.4$ to $1.0 \mathrm{~mm})$ and developed a yellow pigmentation. The colony color of all strains appeared to intensify with age. None of the strains grew under anaerobic conditions, and aerobic growth was not stimulated by increased $\mathrm{CO}_{2}$ concentration (5\%). In stabinoculated tubes of soft SC agar, growth occurred only at the surface whether or not the tubes were overlaid with paraffin oil-petroleum jelly. No requirement for microaerophilic conditions was observed. The optimal temperature for growth appeared to be between 28 and $30^{\circ} \mathrm{C}$ for all strains. The maximum temperature for growth was between 31 and $32^{\circ} \mathrm{C}$ for the strains from sugarcane and between 35 and $36^{\circ} \mathrm{C}$ for the strains from Bermudagrass. All strains grew slowly at room temperature.

Biochemical characterization. All 17 sugarcane strains and 6 Bermudagrass strains were non-acid fast and gram positive. They produced acid from dextrin, D-glucose, mannitol, maltose, and starch but not from adonitol, L-arabinose, arbutin, D-cellobiose, dulcitol, esculin, ethanol, D-fructose, D-galactose, geraniol, i-inositol, inulin, D-lactose, melibiose, D-melezitose, $\beta$-methyl-D-glucoside, propanol, propylene glycol, raffinose, D-ribose, L-rhamnose, salicin, D-sorbitol, D-sucrose, or D-xylose. Casein, corn oil, esculin, gelatin $\left(20^{\circ} \mathrm{C}\right)$, Tween 20 , Tween 80 , tyrosine, and urea were not decomposed. Methyl red tests were negative. Nitrate and nitrite were not reduced. Acetoin and catalase were produced, but $\mathrm{H}_{2} \mathrm{~S}$, indole, ammonium from peptone, oxidase, and gas from glucose were not produced. Acetamide, anthranilate, benzoate, citroaconate, $p$-hydroxybenzoate, $p$-hydroxybutyrate, formate, galacturonate, gluconate, glucuronate, glycolate, lactate, levulinate, maleic acid, malonate, oxalate, propionate, saccharate, succinate, $m$-tartrate, and tryptamine were not utilized. The biochemical and other characteristics which differed among the strains are shown in Table 2. Equivocal test results were generally due to weak reactions which were not consistently positive or negative for a given strain in repeated tests.

Indirect fluorescent antibody reactions with antiserum to sugarcane strain $\mathrm{L}^{\mathrm{T}} \mathrm{A}^{\mathrm{T}}$ were positive for all 17 sugarcane strains and all 6 Bermudagrass strains but not for any of the reference strains tested (11). The sugarcane and Bermuda- 
TABLE 2. Variant characteristics of 17 strains of Clavibacter xyli subsp. xyli sp. nov., subsp. nov. and 6 strains of Clavibacter xyli subsp. cynodontis subsp. nov., including the proposed type strains

\begin{tabular}{|c|c|c|c|c|}
\hline \multirow[b]{2}{*}{ Characteristic } & \multirow[b]{2}{*}{$\begin{array}{c}\text { Reaction of } \\
\text { Clavibacter } \\
\text { xyli subsp. } \\
\text { xyli } \\
\text { (17 strains) }\end{array}$} & \multirow{2}{*}{$\begin{array}{l}\text { Reaction of } \\
\text { Clavibacter } \\
\text { xyli subsp. } \\
\text { cynodontis } \\
\text { (6 strains) }\end{array}$} & \multicolumn{2}{|c|}{ Reactions of type strains } \\
\hline & & & $\begin{array}{l}\text { Clavibacter } \\
\text { xyli subsp. } \\
\text { xyli strain } \\
\text { L1A }\end{array}$ & $\begin{array}{l}\text { Clavibacter } \\
\text { xyli subsp. } \\
\text { cynodontis } \\
\text { strain TB1A }\end{array}$ \\
\hline \multicolumn{5}{|l|}{ Acid from: } \\
\hline Glycerol & $(+)^{a}$ & + & + & + \\
\hline $\begin{array}{l}\text { Mannose } \\
\alpha \text {-Methyl-D- }\end{array}$ & $(+)$ & + & - & + \\
\hline $\begin{array}{l}\alpha \text {-Methyl-D- } \\
\text { glucoside }\end{array}$ & $(+)$ & - & - & - \\
\hline Trehalose & $(+)$ & + & $(+)$ & + \\
\hline Decomposition & & & & \\
\hline \multicolumn{5}{|l|}{ Growth at: } \\
\hline $31^{\circ} \mathrm{C}$ & + & + & + & + \\
\hline $32^{\circ} \mathrm{C}$ & - & + & - & + \\
\hline $35^{\circ} \mathrm{C}$ & - & + & - & + \\
\hline $36^{\circ} \mathrm{C}$ & - & - & - & - \\
\hline \multicolumn{5}{|l|}{$\begin{array}{l}\mathrm{NaCl} \text { toler- } \\
\text { ance: }\end{array}$} \\
\hline $1 \%$ & + & + & + & + \\
\hline $3 \%$ & $(+)$ & + & - & + \\
\hline $5 \%$ & - & -_- & - & - \\
\hline \multicolumn{5}{|l|}{ Pigment } \\
\hline White & + & - & + & - \\
\hline Yellow & - & + & - & + \\
\hline \multicolumn{5}{|l|}{ Utilization of: } \\
\hline Acetate & - & $(+)$ & - & $(+)$ \\
\hline Citrate & - & + & - & + \\
\hline Malate & - & + & - & + \\
\hline
\end{tabular}

${ }^{a}+$, Positive; - , negative; $(+)$, equivocal reaction which was not consistently positive or negative.

grass strains did not grow on yeast extract-sucrose-chalk agar or produce acid from sucrose, unlike all of the reference strains. All strains grew on SC agar. Other characteristics which differentiated the sugarcane and Bermudagrass strains from the reference strains are shown in Table 3 . The RSD broth formulation developed for testing the production of acids from carbohydrates and related compounds and the utilization of organic acids did not support growth of the strains from sugarcane without the addition of an appropriate substrate but did support weak growth of the Bermudagrass strains and most of the reference strains. Growth of a few reference strains in RSD broth without a supplemental substrate resulted in a basic shift in $\mathrm{pH}$. The basic $\mathrm{pH}$ shift may have been due in part to decomposition of the bovine serum albumin in the RSD broth, since deletion of this compound reduced or eliminated the basic reaction. Also, most reference strains that produced the basic reaction decomposed casein or gelatin. Consequently, comparative tests with the reference strains were repeated in RSD broth with and without bovine serum albumin for verification of earlier results.

Cell wall amino acids and sugars. Table 4 shows the major amino acid and sugar components of the cell walls of selected sugarcane strains (strains $\mathrm{L}_{1 \mathrm{~A}}^{\mathrm{T}}, \mathrm{B} 1 \mathrm{~A}$, and $\mathrm{S} 1 \mathrm{~A}$ ), Bermudagrass strain $\mathrm{TB}_{1 \mathrm{~A}} \mathrm{~T}^{\mathrm{T}}$ and the reference strains, as determined by thin-layer and descending paper chromatography. Diaminobutyric acid, glutamic acid, alanine, and glycine were present in the cell walls of both the sugarcane and Bermudagrass strains, as previously reported (11). Diaminobutyric acid, glutamic acid, and alanine were also present in the cell walls of sugarcane and Bermudagrass strains as determined by gas chromatography, but the method used was not satisfactory for detecting ornithine and glycine. In addition, a major peak with a retention time corresponding to that of methionine was found in the cell walls of the strains from both hosts. The major sugars in the cell walls of the sugarcane and Bermudagrass strains were rhamnose and fucose, as previously reported (11). In addition, trace amounts of galactose and glucosamine were detected in the cell walls of these strains.

$G+C$ contents of DNAs. The DNAs of strains $\mathrm{L} \mathrm{A}^{\mathrm{T}}$ and $\mathrm{B} 1 \mathrm{~B}$ from sugarcane and strain $\mathrm{TB} 1 \mathrm{~A}^{\mathrm{T}}$ from Bermudagrass contained $66 \mathrm{~mol} \% \mathrm{G}+\mathrm{C}$.

Polyacrylamide gel electrophoresis. Coryneform bacteria containing diaminobutyric acid in their cell walls were subjected to polyacrylamide gel electrophoresis. Figure 3 shows that Bermudagrass strains $\mathrm{TB} \mathrm{A}^{\mathrm{T}}$ and $\mathrm{FB} 1$ were indistinguishable from each other (Fig. 3, lanes $b$ and $c$ ). Sugarcane strains S1A and $\mathrm{L}_{1 A^{\mathrm{T}}}$ (lanes $\mathrm{d}$ and e) were very similar to each other, but a few distinct differences were evident. Both of the latter strains showed some similarity to strains $T B 1 A^{T}$ and FB1. Overall, the protein patterns of the sugarcane and Bermudagrass strains more closely resembled the patterns of Corynebacterium michiganense subsp. tessellarius (lane h) and Corynebacterium michiganense subsp. michiganense (lane i) than the patterns of other diaminobutyric acid-containing coryneform bacteria. Corynebacterium iranicum (lane f), Corynebacterium rathayi (lane $\mathrm{g}$ ), and Corynebacterium tritici (lane j) were clearly distinguishable from each other and from the other strains examined.

\section{DISCUSSION}

The morphological and biochemical characteristics of the strains from sugarcane and Bermudagrass indicate that these organisms are related to the phytopathogenic coryneform bacteria which contain 2,4-diaminobutyric acid in their cell wall peptidoglycans. All of the strains were gram-positive, non-acid-fast, non-endospore-forming, pleomorphic rods. True mycelia were absent, but primary branching was observed infrequently. Cells were frequently arranged in $\mathrm{V}$ formations, which are characteristic of coryneform bacteria undergoing snapping or bending division. The amino acid and sugar compositions of the cell wall peptidoglycans of the sugarcane and Bermudagrass strains (Table 4) were similar to the compositions found in some phytopathogenic and saprophytic coryneform bacteria in this study and previous studies $(4,7,33-37,40,50)$. The distinctive feature of the cell walls was the presence of 2,4-diaminobutyric acid. In addition, 2,4-diaminobutyric acid was found in the cell wall of Corynebacterium michiganense subsp. tessellarius, supporting the recent classification of this organism (1). The non-hydroxylated long-chain fatty acids of the sugarcane and Bermudagrass strains consist of predominately anteisoand iso-methyl branched acids; only small amounts of straight-chain saturated acids are present (M. Sasser, personal communication). The DNAs of both the sugarcane bacteria and the Bermudagrass bacteria contained $66 \mathrm{~mol} \%$ $\mathrm{G}+\mathrm{C}$, and this is within the range (64 to $74 \mathrm{~mol} \%$ ) for both phytopathogenic and saprophytic coryneform bacteria with cell wall compositions similar to those of the sugarcane and Bermudagrass strains $(27,47)$. The sugarcane and Bermudagrass strains had many polypeptides of apparent common molecular mass as determined by polyacrylamide gel electrophoresis, but the two groups of strains were clearly distinguished. Both bacteria had polypeptides that were more similar to the polypeptides of the Corynebacterium michiganense subspecies than to the polypeptides of other 
2,4-diaminobutyric acid-containing coryneform phytopathogens. It is noteworthy that we confirmed the close relationship of the Corynebacterium michiganense subspecies to each other (Fig. 3, lanes $h$ and $i$ ), which has been observed previously for cells grown in a different medium (1).

There is little consensus as to how the phytopathogenic coryneform bacteria containing 2,4-diaminobutyric acid in their cell wall peptidodglycans should be classified, except that they should be removed from the genus Corynebacterium $(7,15,23,50)$. It is interesting that the separation of phytopathogenic coryneform bacteria into four groups based on the diamino acids in their peptidoglycans (Table 4) agrees exactly with the separation obtained by Dye and Kemp (16) in their numerical phenetic analysis of the phytopathogenic coryneform bacteria. These authors argue that the bacteria in each group or "phenon"' belong to one species. According to their classification, all of the 2,4-diaminobutyric acidcontaining phytopathogenic coryneform bacteria are contained in the species Corynebacterium michiganense. Carlson and Vidaver concluded that Corynebacterium tritici, Corynebacterium iranicum, and Corynebacterium rathayi are significantly different from one another and Corynebacterium michiganense to merit separate specific status based on polyacrylamide gel analyses of cellular proteins. Recent menaquinone analyses support this distinction from Corynebacterium michiganense. The Corynebacterium michiganense subspecies all contain MK-9 as their major isoprenolog, whereas MK-10 is the major isoprenolog of Corynebacterium tritici, Corynebacterium iranicum, and Corynebacterium rathayi $(4,7)$.

Menaquinone composition also distinguishes other 2,4diaminobutyric acid-containing taxa from the phytopathogenic coryneform bacteria, since the former all contain major amounts of MK-10 and MK-11 (Corynebacterium aquaticum), MK-11 and MK-12 (Corynebacterium mediolanum and Flavobacterium dehydrogenans), or MK-12 and MK-13 (Agromyces ramosus) $(3-5,7)$.

On the basis of phenetic and numerical phenetic studies (1, $16,23)$ and cell wall $(4,7,26,33-37,40,50)$, DNA base and DNA homology $(1,15,43,49)$, fatty acid $(3,7,45)$, polar lipid $(3,7,45)$, and menaquinone $(3,5,7,51)$ analyses, we agree with most other workers that the phytopathogenic coryneform bacteria do not belong in the genus Corynebacterium. We believe that valid suggestions have been made for transfer of Corynebacterium fascians to the genus Rhodococcus $(6,20)$, transfer of Corynebacterium ilicis to the genus Arthrobacter (9), and transfer of Corynebacterium flaccumfaciens subsp. flaccumfaciens, Corynebacterium flaccumfaciens subsp. betae, Corynebacterium flaccumfaciens subsp. poinsettiae, and Corynebacterium flaccumfaciens subsp. oortii to the genus Curtobacterium $(8,50)$. However, there appears to be no genus presently circumscribed that can readily accommodate the phytopathogenic coryneform bacteria with peptidoglycans based on 2,4-diaminobutyric acid. Therefore, we propose that a new genus, Clavibacter, be recognized to accommodate these organisms. The saprophytic coryneform bacteria with similar cell wall compositions might also belong in this new genus, but further comparative studies seem to be warranted before such a transfer can be made with confidence. Therefore, we propose that the bacteria presently classified as Cornyebacterium michiganense subsp. michiganense (Smith 1910) Carlson and Vidaver 1982, Corynebacterium michiganense subsp. nebraskense (Schuster et al. 1973) Carlson and Vidaver 1982, Corynebacterium michiganense subsp. insidiosum (McCulloch 1925) Carlson and Vidaver 1982, Coryne- bacterium michiganense subsp. sepedonicum (Spieckermann and Kotthoff 1914) Carlson and Vidaver 1982, Corynebacterium michiganense subsp. tessellarius Carlson and Vidaver 1982, Corynebacterium iranicum (ex Scharif 1961) Carlson and Vidaver 1982, Corynebacterium rathayi (Smith 1913) Dowson 1942, and Corynebacterium tritici (ex Hutchinson 1917) Carlson and Vidaver 1982 be reclassified in the genus Clavibacter gen. nov. as Clavibacter michiganense subsp. michiganense (Smith 1910) comb. nov., Clavibacter michiganense subsp. nebraskense (Schuster et al. 1973) comb. nov., Clavibacter michiganense subsp. insidiosum (McCulloch 1925) comb. nov., Clavibacter michiganense subsp. sepedonicum (Spieckermann and Kotthoff 1914) comb. nov., Clavibacter michiganense subsp. tessellarius (Carlson and Vidaver 1982) comb. nov., Clavibacter iranicum (Carlson and Vidaver 1982) comb. nov., Clavibacter rathayi (Smith 1913) comb. nov., and Clavibacter tritici (Carlson and Vidaver 1982) comb. nov., respectively.

Description of Clavibacter gen. nov. Clavibacter (Cla.vi. bac'ter. L. n. clava cudgel; Gr. masc. n. bakter rod; N. L. masc. n. Clavibacter club-shaped rod) cells are gram-positive, non-acid-fast, pleomorphic rods which are often arranged at an angle to give $\mathrm{V}$ formations; a marked rodcoccus cycle is not observed. Endospores are not formed. Non-motile. Obligately aerobic. Optimum growth temperature is ca. 20 to $29^{\circ} \mathrm{C}$; maximum growth temperature is ca. 29 to $35^{\circ} \mathrm{C}$. Growth occurs on suitable solid medium in air. Nutritionally exacting. Slow and weak oxidative production of acids from some carbohydrates. Some organic acids are utilized. Nitrate is not reduced. Nitrite is not utilized. Catalase positive. Oxidase, tyrosinase, urease, and lipase generally are not produced.

Cell wall peptidoglycan contains 2,4-diaminobutyric acid. Major amounts of rhamnose but not arabinose are found in the cell wall. Does not contain mycolic acids. Non-hydroxylated fatty acids consist predominantly of anteiso- and isomethyl branched chains; minor amounts of straight-chain saturated acids are found. Respiratory quinones are menaquinones. Polar lipids comprise diphosphatidylglycerol, phosphatidylglycerol, and glycolipids.

The DNA base composition is about $70 \pm 5 \mathrm{~mol} \% \mathrm{G}+\mathrm{C}$. The type species is Clavibacter michiganense.

Characteristics which can be used to differentiate the sugarcane and Bermudagrass strains from the reference strains, which include most of the type strains of the phytopathogenic coryneform bacteria, are listed in Table 3 . The slow growth and fastidious nature of the sugarcane and Bermudagrass strains relative to the reference strains are obvious differential characteristics; the sugarcane and Bermudagrass strains grow only in media that were specifically developed for them in both this study and previous studies $(10,30)$. The inability of all sugarcane and Bermudagrass strains to produce acid from sucrose and the distinct serological properties of these organisms (11) also distinguish them from all other strains examined.

In our opinion, the sugarcane and Bermudagrass strains clearly form distinct taxa in the new genus Clavibacter on the basis of their morphological and biochemical characteristics. We believe that the differences between the strains from sugarcane and the strains from Bermudagrass are insufficient to warrant establishment of separate species. However, the two groups are distinct and thus, in our opinion, warrant subspecies status. Characteristics of the sugarcane strains which distinguish them from the Bermudagrass strains are their characteristic protein bands in polyacrylamide gels, 
TABLE 3. Characteristics for differentiation of Clavibacter xyli subsp. xyli sp. nov., subsp. nov. and Clavibacter xyli subsp. cynodontis subsp. nov. from taxa of Corynebacterium, Agromyces ramosus, and Mycobacterium fortuitum

\begin{tabular}{|c|c|c|c|c|c|c|c|c|c|c|}
\hline \multirow{2}{*}{ Organism } & \multirow{2}{*}{ Pigment $^{a}$} & \multirow{2}{*}{$\begin{array}{c}\text { Diamino } \\
\text { acid in } \\
\text { peptidoglycan }\end{array}$} & \multicolumn{2}{|c|}{$\begin{array}{l}\text { Cell wall } \\
\text { contains: }\end{array}$} & \multicolumn{3}{|c|}{ Acid production from: } & \multicolumn{3}{|c|}{ Acid production from: } \\
\hline & & & $\begin{array}{l}\text { Rham- } \\
\text { nose }\end{array}$ & $\begin{array}{l}\text { Fu- } \\
\text { cose }\end{array}$ & $\begin{array}{l}\text { Rham- } \\
\text { nose }\end{array}$ & $\begin{array}{c}\text { Manni- } \\
\text { tol }\end{array}$ & $\begin{array}{c}\text { Ri- } \\
\text { bose }\end{array}$ & $\begin{array}{l}\text { Melezi- } \\
\text { tose }\end{array}$ & $\begin{array}{l}\text { Sorbi- } \\
\text { tol }\end{array}$ & $\begin{array}{c}\text { Inu- } \\
\text { lin }\end{array}$ \\
\hline Clavibacter xyli, subsp. xyli & W & $\mathrm{DAB}$ & + & + & - & + & - & - & - & - \\
\hline Clavibacter xyli, subsp. cynodontis & $\mathrm{Y}$ & $\mathrm{DAB}$ & + & + & - & + & - & - & - & _ \\
\hline Agromyces ramosus & W & $\mathrm{DAB}$ & + & - & + & - & + & - & - & + \\
\hline $\begin{array}{l}\text { Corynebacterium michiganense subsp. } \\
\text { michiganense }\end{array}$ & $\mathrm{Y}$ & $\mathrm{DAB}$ & + & + & - & $+^{d}$ & - & $t^{d}$ & - & - \\
\hline Corynebacterium michiganense subsp. insidiosum & W & $\mathrm{DAB}$ & + & + & - & $+{ }^{d}$ & - & - & - & - \\
\hline $\begin{array}{l}\text { Corynebacterium michiganense subsp. } \\
\text { nebraskense }\end{array}$ & $\mathrm{O}$ & DAB & \pm & + & - & $+^{d}$ & - & - & $+^{d}$ & - \\
\hline $\begin{array}{l}\text { Corynebacterium michiganense subsp. } \\
\text { sepedonicum }\end{array}$ & W & DAB & + & - & - & + & - & - & $+^{d}$ & - \\
\hline Corynebacterium michiganense subsp. tessellarius & $\mathrm{O}$ & $\mathrm{DAB}$ & + & + & - & + & - & - & + & - \\
\hline Corynebacterium iranicum & $\mathrm{Y}$ & DAB & + & - & - & $+^{d}$ & - & $-{ }^{d}$ & - & $+^{d}$ \\
\hline Corynebacterium rathayi & $\mathrm{Y}$ & $\mathrm{DAB}$ & + & - & - & + & - & - & - & - \\
\hline Corynebacterium tritici & $\mathrm{Y}$ & DAB & + & - & - & + & - & - & - & + \\
\hline $\begin{array}{l}\text { Corynebacterium flaccumfaciens subsp. } \\
\text { flaccumfaciens }\end{array}$ & $\mathrm{Y}$ & Orn & + & + & + & + & + & + & - & - \\
\hline Corynebacterium flaccumfaciens subsp. betae & Y & Orn & + & + & + & + & + & + & + & - \\
\hline Corynebacterium flaccumfaciens subsp. oortii & $\mathrm{Y}$ & Orn & + & + & + & + & + & + & - & - \\
\hline $\begin{array}{l}\text { Corynebacterium flaccumfaciens subsp. } \\
\text { poinsettiae }\end{array}$ & $\mathrm{O}$ & Orn & + & - & $-{ }^{d}$ & + & + & + & + & - \\
\hline Corynebacterium illicis & $\mathrm{Y}$ & Lys $^{e}$ & - & - & $-{ }^{d}$ & + & + & + & $-{ }^{d}$ & $-{ }^{d}$ \\
\hline Corynebacterium fascians & $\mathrm{O}$ & DAP & - & - & - & + & + & - & + & - \\
\hline Mycobacterium fortuitum & W & DAP & - & - & - & + & + & - & - & - \\
\hline
\end{tabular}

a Pigmentation of colonies on SC agar. Y, yellow; O, orange; W, white.

${ }^{b}$ DAB, Diaminobutyric acid; Orn, ornithine; Lys, lysine; DAP, meso-diaminopimelic acid.

c Tween 80 was used as the substrate.

${ }^{d}$ Data disagree with the data obtained by Dye and Kemp (16), who used the same strain but performed their experiments under different conditions.

e Data from reference 26 .

slower growth rate on SC agar, small maximum colony size on SC agar, white color (as opposed to yellow pigmentation), and inability to utilize citrate and malate. Descriptions of the new taxa are given below.

Clavibacter xyli subsp. xyli sp. nov., subsp. nov. Clavibacter xyli subsp. xyli (xy'li. xylon wood; N. L. gen. $\mathrm{n}$. xyli of the xylem) cells are gram-positive, non-acid-fast, non-endospore-forming, pleomorphic rods that are nonmotile and measure approximately 0.2 by $5.0 \mu \mathrm{m}$. Colonies on SC agar are circular with entire margins (diameter, 0.1 to $0.3 \mathrm{~mm}$ ), convex, glistening, and butyrous. All strains are obligate aerobes. Optimal growth occurs between 26 and $30^{\circ} \mathrm{C}$; strains do not grow at $32^{\circ} \mathrm{C}$. Colonies of all strains gradually produce a white color that intensifies with the age of the culture. All strains produce acid from oxidative fermentation of glucose, maltose, starch, and dextrin; acid is not produced from adonitol, arabinose, arbutin, cellobiose, dulcitol, esculin, ethanol, fructose, galactose, geraniol, inositol, inulin, lactose, melibiose, melezitose, $\beta$-methyl-D-glucoside, propanol, propylene glycol, raffinose, rhamnose, salicin, sorbitol, sucrose, or xylose. Gas is not produced from glucose metabolism. Casein, corn oil, esculin, gelatin, starch, Tween 20 , Tween 80 , tyrosine, and urea are not decomposed. $\mathrm{KCN}$ is tolerated at a concentration of $0.0075 \%$ in RSD broth. Nitrate and nitrite are not reduced. Catalase and acetoin are produced, but $\mathrm{H}_{2} \mathrm{~S}$, indole, ammonium from peptone, and oxidase are not produced. Acetate, acetamide, anthranilate, benzoate, citrate, citroaconate, $p$-hydroxybenzoate, $\beta$-hydroxybutyrate, formate, fumarate, galacturonate, gluconate, glucuronate, glycolate, lactate, levulinate, malate, maleic acid, malonate, oxalate, propionate, saccharate, succinate, $m$-tartrate, and tryptamine are not utilized.

This taxon is distinguished from other coryneform bacteria on the basis of the $\mathrm{G}+\mathrm{C}$ content $(66 \mathrm{~mol} \%)$ of its DNA, the presence of diaminobutyric acid in its peptidoglycan, and its distinct pattern of protein bands in polyacrylamide gels. It is distinguished from the other subspecies of Clavibacter xyli sp. nov. by its colony pigment, colony size, inability to utilize citrate and malate, inability to hydrolyze starch, protein pattern in polyacrylamide gels, and ability to induce ratoon stunting disease in sugarcane (Saccharum interspecific hybrids).

The type strain of the species and subspecies is strain L1A $(=$ NCPPB $3152=$ PDDCC $7127=$ ATCC 33974). The description given above is based on 17 strains which are virtually indistinguishable; thus, the subspecies description is also the type strain description.

Clavibacter xyli subsp. cynodontis subsp. nov. Clavibacter xyli subsp. cynodontis (cy.no.don'tis. N.L. n. Cynodon genus of Bermudagrass; N.L. gen. n. cynodontis of Bermudagrass) cells are gram-positive, non-acid-fast, non-endospore-forming, pleomorphic rods that are nonmotile and measure approximately 0.2 by $5.0 \mu \mathrm{m}$. Colonies on $\mathrm{SC}$ agar are circular with entire margins (diameter, 0.4 to $1.0 \mathrm{~mm}$ ), convex, glistening, and butryous. All strains are obligate aerobes. Optimal growth occurs at 26 to $30^{\circ} \mathrm{C}$; strains do not grow at $36^{\circ} \mathrm{C}$. All strains produce a yellow pigment which intensifies with the age of the culture. All strains produce acid from oxidative fermentation of dextrin, glucose, glycerol, mannitol, mannose, maltose, starch, and trehalose; acid 
TABLE 3-Continued

\begin{tabular}{|c|c|c|c|c|c|c|c|c|c|c|c|c|c|c|c|c|c|c|}
\hline \multicolumn{6}{|c|}{ Utilization of: } & \multirow{2}{*}{$\begin{array}{l}\text { Nitrate } \\
\text { reduc- } \\
\text { tion }\end{array}$} & \multirow{2}{*}{$\begin{array}{l}\text { Meth- } \\
\text { yl red }\end{array}$} & \multirow{2}{*}{$\begin{array}{c}\mathrm{KCN} \\
\text { toler- } \\
\text { ance }\end{array}$} & \multirow{2}{*}{$\begin{array}{l}\text { Levan } \\
\text { produc- } \\
\text { tion }\end{array}$} & \multicolumn{5}{|c|}{ Production of: } & \multicolumn{4}{|c|}{ Hydrolysis of: } \\
\hline $\begin{array}{l}\text { Ace- } \\
\text { tate }\end{array}$ & $\begin{array}{l}\text { Cit- } \\
\text { rate }\end{array}$ & $\begin{array}{l}\text { Malo- } \\
\text { nate }\end{array}$ & $\begin{array}{l}\text { Propio- } \\
\text { nate }\end{array}$ & $\begin{array}{l}\text { Fumar- } \\
\text { ate }\end{array}$ & $\begin{array}{l}\text { For- } \\
\text { mate }\end{array}$ & & & & & $\mathrm{H}_{2} \mathrm{~S}$ & $\begin{array}{c}\mathrm{Li}- \\
\text { pase }^{r}\end{array}$ & $\begin{array}{l}\text { Ure- } \\
\text { ase }\end{array}$ & $\begin{array}{l}\text { Tyro- } \\
\text { sinase }\end{array}$ & $\begin{array}{l}\text { Ace- } \\
\text { toin }\end{array}$ & $\begin{array}{l}\mathrm{Ca}- \\
\text { sein }\end{array}$ & $\begin{array}{c}\text { Escu- } \\
\text { lin }\end{array}$ & $\begin{array}{c}\text { Gela- } \\
\text { tin }\end{array}$ & Starch \\
\hline - & - & - & - & - & - & - & - & + & - & - & - & - & - & - & - & - & - & - \\
\hline- & + & - & - & - & - & - & - & + & - & - & - & - & - & + & - & - & - & + \\
\hline+ & - & - & - & + & - & - & - & + & - & - & - & - & - & - & - & - & - & + \\
\hline$-d$ & + & - & - & + & - & - & $+^{d}$ & + & $+{ }^{d}$ & + & - & - & - & + & - & + & + & + \\
\hline - & + & - & $+^{d}$ & + & - & - & + & - & $+^{d}$ & $+^{d}$ & - & - & - & + & - & + & - & + \\
\hline+ & + & - & - & + & - & - & - & + & + & + & - & - & - & - & - & + & - & + \\
\hline+ & + & - & - & + & - & - & - & $+{ }^{d}$ & - & - & - & - & - & - & - & + & - & $-{ }^{d}$ \\
\hline - & + & - & - & + & - & - & - & + & + & + & - & - & - & + & - & + & - & + \\
\hline - & + & - & - & + & - & - & - & $+^{d}$ & - & $-d$ & - & - & - & - & - & + & - & - \\
\hline - & + & - & - & + & - & - & + & $+{ }^{d}$ & $-{ }^{t} t$ & + & - & - & - & - & - & + & $-d$ & + \\
\hline+ & + & - & - & + & - & - & $+^{d}$ & $+{ }^{d}$ & - & $-d$ & - & - & - & - & - & + & - & - \\
\hline+ & + & - & - & + & - & - & + & + & - & + & - & - & - & - & + & + & $+^{d}$ & + \\
\hline+ & + & - & - & - & - & - & + & $+^{d}$ & - & + & $-{ }^{d}$ & - & - & - & - & + & - & + \\
\hline- & + & - & - & $+^{d}$ & - & - & + & + & - & + & - & - & - & - & + & + & $t^{d}$ & + \\
\hline+ & + & - & - & $+^{d}$ & - & $+^{d}$ & + & - & - & - & - & - & - & $-^{d}$ & + & + & - & + \\
\hline+ & + & + & + & + & + & - & + & + & - & + & - & $-^{d}$ & - & - & + & $+^{d}$ & + & - \\
\hline+ & + & + & + & + & + & - & - & + & - & - & + & + & $+{ }^{d}$ & - & - & - & - & $-d$ \\
\hline+ & + & + & + & + & + & - & - & + & - & - & - & - & - & - & - & - & - & + \\
\hline
\end{tabular}

is not produced from adonitol, arabinose, arbutin, cellobiose, dulcitol, esculin, ethanol, fructose, galactose, geraniol, i-inositol, inulin, lactose, melibiose, melezitose, $\alpha$-methyl-Dglucoside, $\beta$-methyl-D-glucoside, propanol, propylene glycol, raffinose, ribose, rhamnose, salicin, sorbitol, sucrose, or xylose. Gas is not produced from glucose metabolism. Starch is hydrolyzed, but casein, corn oil, esculin, gelatin,
Tween 20, Tween 80, tyrosine, and urea are not decomposed. $\mathrm{KCN}$ is tolerated at a concentration of $0.0075 \%$ in RSD broth. Nitrate and nitrite are not reduced. Catalase and acetoin are produced, but $\mathrm{H}_{2} \mathrm{~S}$, indole, ammonium from peptone, and oxidase are not produced. Citrate and malate are utilized, but acetamide, anthranilate, benzoate, citroacontate, $p$-hydroxybenzoate, $\beta$-hydroxybutyrate, formate,

TABLE 4. Cell wall amino acids and sugars of Clavibacter xyli subsp. xyli sp. nov., subsp. nov., Clavibacter xyli subsp. cynodontis subsp. nov., taxa of Corynebacterium, Agromyces ramosus, and Mycobacterium fortuitum

\begin{tabular}{|c|c|c|c|c|c|c|c|c|c|c|c|}
\hline \multirow[b]{2}{*}{ Organism } & \multicolumn{4}{|c|}{ Amino acids ${ }^{a}$} & \multicolumn{7}{|c|}{ Sugars } \\
\hline & $\mathrm{DAB}$ & $m$-DAP & $\begin{array}{l}\text { Orni- } \\
\text { thine }\end{array}$ & $\begin{array}{l}\text { Gly- } \\
\text { cine }\end{array}$ & $\begin{array}{l}\text { Galac- } \\
\text { tose }\end{array}$ & $\begin{array}{l}\text { Glu- } \\
\text { cose }\end{array}$ & $\begin{array}{l}\text { Man- } \\
\text { nose }\end{array}$ & $\begin{array}{l}\text { Arab- } \\
\text { inose }\end{array}$ & $\begin{array}{l}\mathrm{Xy}- \\
\text { lose }\end{array}$ & $\begin{array}{l}\text { Fu- } \\
\text { cose }\end{array}$ & $\begin{array}{l}\text { Rham- } \\
\text { nose }\end{array}$ \\
\hline Clavibacter xyli subsp. $x y l i^{b}$ & $+c$ & - & - & + & $(+)$ & - & - & - & - & + & + \\
\hline Clavibacter xyli subsp. cynodontis ${ }^{d}$ & + & - & - & + & $(+)$ & - & - & - & - & + & + \\
\hline Agromyces ramosus & + & - & - & + & $(+)$ & + & + & - & + & - & + \\
\hline Corynebacterium michiganense subsp. michiganense & + & - & - & + & + & - & + & - & - & + & + \\
\hline Corynebacterium michiganense subsp. insidiosum & + & - & - & + & + & - & + & - & - & + & + \\
\hline Corynebacterium michiganense subsp. nebraskense & + & - & - & + & + & - & - & - & - & + & $(+)$ \\
\hline Corynebacterium michiganense subsp. sepedonicum & + & - & - & + & + & $(+)$ & + & - & - & - & + \\
\hline Corynebacterium michiganense subsp. tessellarius & + & - & - & + & + & - & - & - & - & + & + \\
\hline Corynebacterium iranicum & + & - & - & + & $(+)$ & + & + & - & - & - & + \\
\hline Corynebacterium rathayi & + & - & - & + & $(+)$ & + & + & - & + & - & + \\
\hline Corynebacterium tritici & + & - & - & + & $(+)$ & + & + & - & + & - & + \\
\hline Corynebacterium flaccumfaciens subsp. flaccumfaciens & - & - & + & + & + & - & + & - & - & - & + \\
\hline Corynebacterium flaccumfaciens subsp. betae & - & - & + & + & - & - & + & - & - & + & + \\
\hline Corynebacterium flaccumfaciens subsp. oortii & - & - & + & + & - & + & + & - & - & + & + \\
\hline Corynebacterium flaccumfaciens subsp. poinsettiae & - & - & + & + & + & $(+)$ & + & - & - & - & + \\
\hline Corynebacterium illicis & - & - & - & + & + & $(+)$ & + & - & - & - & - \\
\hline Corynebacterium fascians & - & + & - & - & + & $(+)$ & $(+)$ & + & - & - & - \\
\hline Mycobacterium fortuitum & - & + & - & - & + & + & - & + & - & - & - \\
\hline
\end{tabular}

${ }^{a}$ Alanine and glutamic acid were major cell wall components of all strains. DAB, 2,4-Diaminobutyric acid; $m$-DAP, meso-diaminopimelic acid.

${ }^{b}$ Based on an analysis of strains $\mathrm{L}^{\mathrm{A}} \mathrm{A}^{\mathrm{T}}, \mathrm{S} 1 \mathrm{~A}$, and $\mathrm{B} 1 \mathrm{~A}$

$c+$. Detected; - , not detected; $(+)$, weak or questionable.

${ }^{d}$ Based on an analysis of strain $\mathrm{TB}_{1} \mathrm{~A}^{\mathrm{T}}$. 


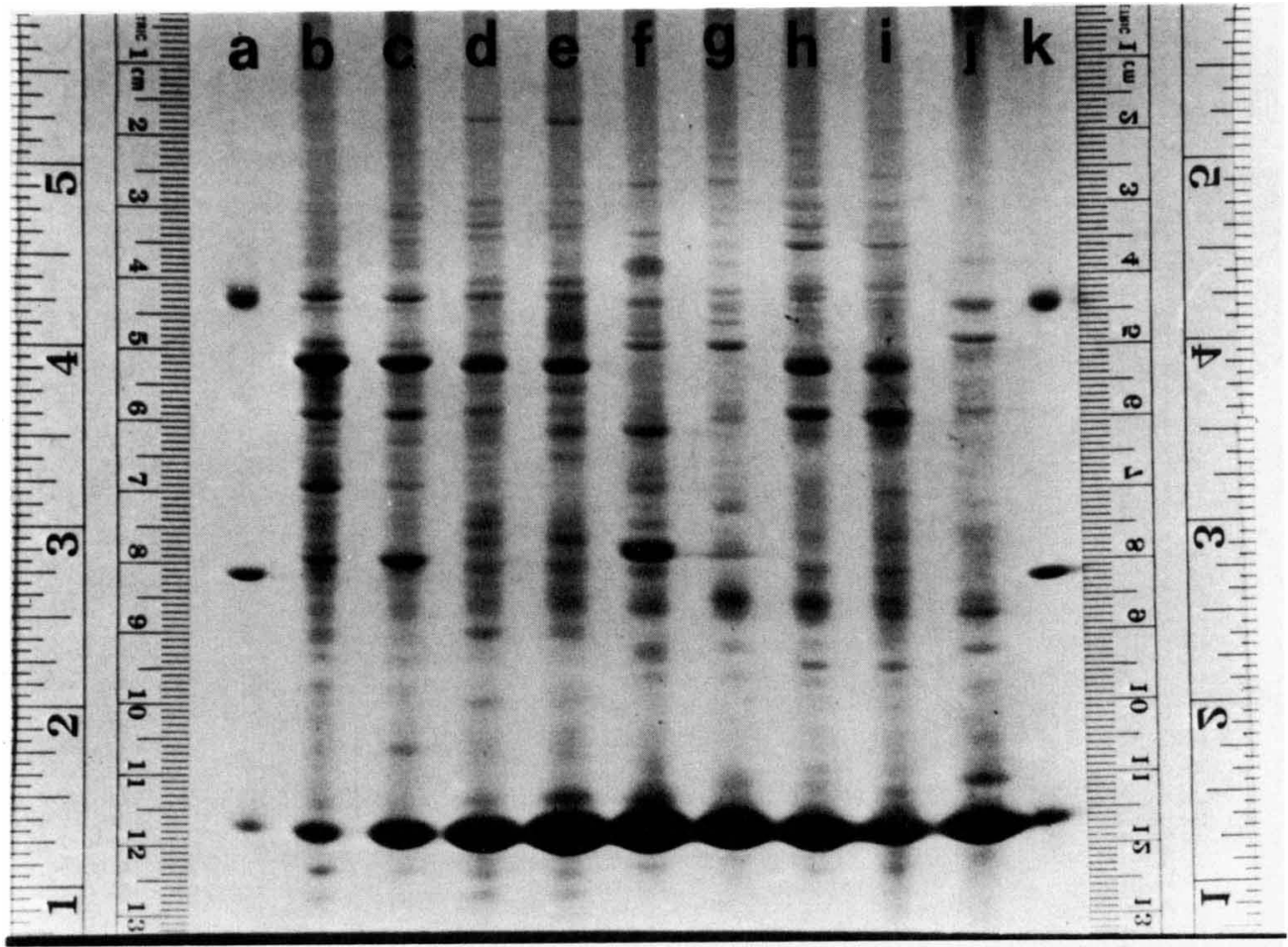

FIG. 3. Protein patterns of diaminobutyric acid-containing corynebacteria in a polyacrylamide slab gel. Samples were electrophoresed from top to bottom. Lanes a and $\mathrm{k}$ contained standard proteins (top to bottom) bovine serum albumin (molecular weight, 66,300), carbonic anhydrase $B(28,000)$, and lysozyme $(14,300)$. Lanes b through $j$ contained extracts from Bermudagrass strains TB1A ${ }^{\mathrm{T}}$ and $\mathrm{FB} 1$, sugarcane strains S1A and $\mathrm{LlA}^{\mathrm{T}}$, Corynebacterium iranicum, Corynebacterium rathayi, Corynebacterium michiganense subsp. tessellarius, Corynebacterium michiganense subsp. michiganense, and Corynebacterium tritici, respectively. In each sample residual lysozyme served as an internal marker.

galacturonate, gluconate, glucuronate, glycolate, lactate, levulinate, maleic acid, malonate, oxalate, propionate, saccharate, succinate, $m$-tartrate, and tryptamine are not utilized.

This taxon is distinguished from other coryneform bacteria on the basis of the $\mathrm{G}+\mathrm{C}$ content $(66 \mathrm{~mol} \%)$ of its DNA, the presence of diaminobutyric acid in its peptidoglycan, and its distinct pattern of protein bands in polyacrylamide gels. It is distinguished from the other subspecies of Clavibacter $x y l i$ sp. nov. by its yellow pigmentation, colony size, ability to utilize citrate and malate, ability to hydrolyze starch, distinct protein bands in polyacrylamide gels, and ability to induce Bermudagrass stunting disease in Bermudagrass [Cynodon dactylon (L.) Pers].

The type strain is strain TB1A (= ATCC 33973). The subspecies description given above is based on six strains, which are virtually indistinguishable; thus, the subspecies description is also the type strain description.

\section{ACKNOWLEDGMENTS}

We thank R. R. Carlson and W. P. Haskins for assistance with the gel electrophoresis of proteins, D. Kuczmarski for photographic assistance, D. S. Williams for the electron micrographs, R. E Gordon and M. P. Lechevalier for advice on performing cell wall analyses, and T. O. MacAdoo for assistance with Latin and Greek. We also thank M. D. Collins and J. Bradbury for a draft of their chapter on plant pathogenic "Corynebacteria" for the forthcoming edition of Bergey's Manual of Determinative Bacteriology.

This work was supported in part by grant 80-CRCR-1-0532 from the Competitive Research Grants Office, Science and Education Administration, United States Department of Agriculture.

\section{LITERATURE CITED}

1. Carlson, R. R., and A. K. Vidaver. 1982. Taxonomy of Corynebacterium plant pathogens, including a new pathogen of wheat, based on polyacrylamide gel electrophoresis of cellular proteins. Int. J. Syst. Bacteriol. 32:315-326.

2. Chassy, B. M., and A. Giuffrida. 1980. Method for the lysis of gram-positive, asporogenous bacteria with lysozyme. Appl. Environ. Microbiol. 39:153-158.

3. Collins, M. D. 1982. Lipid-composition of Agromyces ramosus (Gledhill and Casida). FEMS Microbiol. Lett. 14:187-189.

4. Collins, M. D. 1983. Cell wall peptidoglycan and lipid composition of the phytopathogen Corynebacterium rathayi (Smith). Syst. Appl. Microbiol. 4:193-198.

5. Collins, M. D., M. Goodfellow, and D. E. Minnikin. 1979. Isoprenoid quinones in the classification of coryneform and related bacteria. J. Gen. Microbiol. 110:127-136.

6. Collins, M. D., M. Goodfellow, and D. E. Minnikin. 1982. A survey of structures of mycolic acids in Corynebacterium and related taxa. J. Gen. Microbiol. 128:129-149.

7. Collins, M. D., and D. Jones. 1980 . Lipids in the classification and identification of coryneform bacteria containing peptidoglycans based on 2,4-diaminobutyric acid. J. Appl. Bacteriol. 48:459-470.

8. Collins, M. D., and D. Jones. 1983. Reclassification of Corynebacterium flaccumfaciens, Corynebacterium betae, Corynebacterium oortii and Corynebacterium poinsettiae in the genus Curtobacterium, as Curtobacterium flaccumfaciens comb. nov. J. Gen. Microbiol. 129:3545-3548.

9. Collins, M. D., D. Jones, and R. M. Kroppenstedt. 1981. Reclassification of Corynebacterium ilicis (Mandel, Guba and Litsky) in the genus Arthrobacter, as Arthrobacter ilicis comb. nov. Zentralbl. Bakteriol. Parasitenkd. Infektionskr. Hyg. Abt. 1 Orig. Reihe C 2:318-323.

10. Davis, M. J., A. G. Gillaspie, Jr., R. W. Harris, and R. H. 
Lawson. 1980. Ratoon stunting disease of sugarcane: isolation of the causal bacterium. Science 210:1365-1367.

11. Davis, M. J., R. H. Lawson, A. G. Gillaspie, Jr., and R. W. Harris. 1983. Properties and relationships of two xylem-limited bacteria and a mycoplasmalike organism infecting Bermudagrass. Phytopathology 73:341-346.

12. Davis, M. J., R. F. Whitcomb, and A. G. Gillaspie, Jr. 1981. Fastidious bacteria of plant vascular tissue and invertebrates (including so-called rickettsia-like bacteria), p. 2172-2188. In M. P. Starr, H. Stolp, H. G. Trüper, A. Balows, and H. G. Schlegel (ed.), The prokaryotes, a handbook on habitats, isolation, and identification of bacteria. Springer-Verlag, Berlin.

13. Diaz-Ruiz, J. R., and J. M. Kaper. 1978. Isolation of viral double-stranded RNAs using a $\mathrm{LiCl}$ fractionation procedure. Prep. Biochem. 8:1-17.

14. Doetsch, R. N. 1981. Determinative methods of light microscopy, p. 21-51. In P. Gerhardt, R. G. E. Murray, R. N. Costilow, E. W. Nester, W. A. Wood, N. R. Krieg, and G. B. Phillips (ed.), Manual of methods for general bacteriology. American Society for Microbiology, Washington, D.C.

15. Döpfer, H., E. Stackebrandt, and F. Fiedler. 1982. Nucleic acid hybridization studies on Microbacterium, Curtobacterium, Agromyces and related taxa. J. Gen. Microbiol. 128:1697-1708.

16. Dye, D. W., and W. J. Kemp. 1977. A taxonomy study of plant pathogenic Corynebacterium species. N. Z. J. Agric. Res. 20:563-582.

17. Fiedler, F., and O. Kandler. 1973. Die Aminosäuresequenz von 2,4-Diaminobuttersäure enthaltenden Mureinen bei verscheidenen coryneformen Bakterien und Agromyces ramosus. Arch. Mikrobiol. 89:51-66.

18. Gillaspie, A. G., Jr. 1978. Ratoon stunting disease of sugarcane: serology. Phytopathology 68:529-532.

19. Gillaspie, A. G., Jr., R. E. Davis, and J. F. Worley. 1973. Diagnosis of ratoon stunting disease based on the presence of a specific microorganism. Plant Dis. Rep. 59:987-990.

20. Goodfellow, M., and G. Alderson. 1977. The actinomycete genus Rhodococcus: a home for the 'rhodochrous' complex. J. Gen. Microbiol. 100:99-122.

21. Hill, L. R. 1966. An index to deoxyribonucleic acid base compositions of bacterial species. J. Gen. Microbiol. 44:419-437.

22. Jensen, H. L. 1952. The coryneform bacteria. Annu. Rev. Microbiol. 6:77-90.

23. Jones, D. 1975. A numerical taxonomic study of coryneform and related bacteria. J. Gen. Microbiol. 87:52-96.

24. Kado, C. I., and M. G. Heskett. 1970. Selective media for isolation of Agrobacterium, Corynebacterium, Erwinia, Pseudomonas, and Xanthomonas. Phytopathology 60:969-976.

25. Kao, J., and K. E. Damann, Jr. 1978. Microcolonies of the bacterium associated with ratoon stunting disease found in sugarcane xylem matrix. Phytopathology 68:545-551.

26. Keddie, R. M., and G. L. Cure. 1977. The cell wall composition and distribution of free mycolic acids in named strains of coryneform bacteria and in isolates from various natural sources. J. Appl. Bacteriol. 42:229-252.

27. Keddie, R. M., and D. Jones. 1981. Saprophytic, aerobic coryneform bacteria, p. 1838-1878. In M. P. Starr, H. Stolp, H. G. Trüper, A. Balows, and H. G. Schlegel (ed.), The prokaryotes, a handbook on habitats, isolation, and identification of bacteria. Springer-Verlag, Berlin.

28. Kovacs, N. 1956. Identification of Pseudomonas pyocyanea by the oxidase reaction. Nature (London) 178:703.

29. Lechevalier, M. P., and H. A. Lechevalier. 1980. Chemotaxonomy of actinomycetes, p. 227-291. In A. Dietz and D. W. Thayer (ed.), Actinomycete taxonomy. Society for Industrial Microbiology, Arlington, Va.

30. Liao, C. H., and T. A. Chen. 1981. Isolation, culture, and pathogenicity to Sudan grass of a corynebacterium associated with ratoon stunting of sugarcane and with Bermuda grass Phytopathology 71:1303-1306.

31. Maramorosch, K., B. Plavsic-Banjac, J. Bird, and L. J. Liu.
1973. Electron microscopy of ratoon stunted sugar cane: microorganisms in xylem. Phytopathol. Z. 77:270-273.

32. Marmur, J., and P. Doty. 1962. Determination of the base composition of deoxyribonucleic acid from its thermal denaturation temperature. J. Mol. Biol. 5:109-118.

33. Perkins, H. R. 1967. The use of photolysis of dinitrophenylpeptides in structural studies on the cell-wall mucopeptide of Corynebacterium poinsettiae. Biochem. J. 102:29c-32c.

34. Perkins, H. R. 1968. Cell wall mucopeptide of Corynebacterium insidiosum and Corynebacterium sepedonicum. Biochem. J. 110:47-48.

35. Perkins, H. R. 1970. Extraction procedures and cell wall composition, including some results with corynebacteria. Int. J. Syst. Bacteriol. 20:379-382.

36. Perkins, H. R. 1971. Homoserine and diaminobutyric acid in the mucopeptide-precursor-nucleotides and cell walls of some plant-pathogenic corynebacteria. Biochem. J. 121:417-423.

37. Perkins, H. R., and C. S. Cummins. 1964. Ornithine and 2,4 diaminobutyric acid as components of the cell wall of plant pathogenic corynebacteria. Nature (London) 201:1105-1107.

38. Rhodes, D., A. C. Myers, and G. Jamieson. 1981. Gas chromatography-mass spectrometry of N-heptafluorobutyryl isobutyl esters of amino acids in the analysis of the kinetics of $\left({ }^{15} \mathrm{~N}\right) \mathrm{H}^{+}$ assimilation in Lemna minor L. Plant Physiol. 8:1197-1205.

39. Roessler, W. G., and L. S. McClung. 1943. Suggested method for the use of vanillin as a test reagent for indole and skatole production by bacteria. J. Bacteriol. 45:413.

40. Schleifer, K. H., and O. Kandler. 1972. Peptidoglycan types of bacterial cell walls and their taxonomic implications. Bacteriol. Rev. 36:407-477.

41. Skerman, V. B. D., V. McGowan, and P. H. A. Sneath (ed.) 1980. Approved lists of bacterial names. Int. J. Syst. Bacteriol. 30:225-420.

42. Smibert, R. M., and N. R. Krieg. 1981. General characterization, p. 409-443. In P. Gerhardt, R. G. E. Murray, R. N Costilow, E. W. Nester, W. A. Wood, N. R. Krieg, and G. B. Phillips (ed.), Manual of methods for general bacteriology. American Society for Microbiology, Washington, D.C.

43. Starr, M. P., M. Mandel, and N. Murata. 1975. The phytopathogenic coryneform bacteria in light of DNA base composition and DNA-DNA segmental homology. J. Gen. Appl. Microbiol. 21:13-26.

44. Steindl, D. R. L. 1961. Ratoon stunting disease, p. 433-459. In J. P. Martin, E. V. Abbott, and C. G. Hughes (ed.), Sugarcane diseases of the world, vol. 1. Elsevier Publishing Co., Amsterdam.

45. Suzuki, K.-I., and K. Komkagata. 1983. Taxonomic significance of cellular fatty acid composition in some coryneform bacteria. Int. J. Syst. Bacteriol. 33:188-200.

46. Teakle, D. S., P. M. Smith, and D. R. L. Steindl. 1973. Association of a small coryneform bacterium with the ratoon stunting disease of sugarcane. Aust. J. Agric. Res. 24:869-874.

47. Vidaver, A. K., and M. P. Starr. 1981. Phytopathogenic coryneform and related bacteria, p. 1879-1887. In M. P. Starr, H. Stolp, H. G. Trüper, A. Balows, and H. G. Schlegel (ed.), The prokaryotes, a handbook on habitats, isolation, and identification of bacteria. Springer-Verlag, Berlin.

48. Weaver, L., D. S. Teakle, and A. C. Hayward. 1977. Ultrastructural studies on the bacterium associated with ratoon stunting disease of sugar-cane. Aust. J. Agric. Res. 28:843-852.

49. Yamada, K., and K. Komagata. 1970. Taxonomic studies on coryneform bacteria. III. DNA base composition of coryneform bacteria. J. Gen. Appl. Microbiol. 16:215-224.

50. Yamada, K., and K. Komagata. 1972. Taxonomic studies on coryneform bacteria. V. Classification of coryneform bacteria. J. Gen. Appl. Microbiol. 18:417-431.

51. Yamada, Y., G. Inouye, Y. Tahara, and K. Kondo. 1976. The menaquinone system in the classification of coryneform and nocardioform bacteria and related organisms. J. Gen. Appl. Microbiol. 22:203-214. 